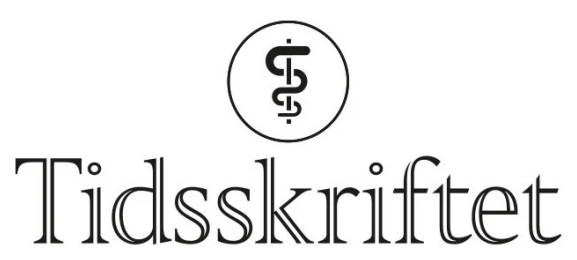

DEN NORSKE LEGEFORENING

\title{
Pragmatiske studier - hva er det?
}

\section{KRONIKK}

\author{
MAGNUS NAKREM LYNGBAKKEN \\ magnus.lyngbakken@medisin.uio.no \\ Magnus Nakrem Lyngbakken er lege ved Infeksjonsmedisinsk avdeling og postdoktor ved Medisinsk \\ divisjon, Akershus universitetssykehus. Han er arbeidspakkeleder for Pragmatiske studier og \\ registerbaserte kliniske studier i det nasjonale forskningsstøttenettverket NorCRIN. \\ Forfatteren har fylt ut ICMJE-skjemaet og oppgir ingen interessekonflikter.
}

\section{AKSEL PAULSEN}

Aksel Paulsen er ph.d., spesialist i ortopedisk kirurgi, seksjonsoverlege ved Stavanger universitetssjukehus og førsteamanuensis II ved Universitetet i Stavanger. Forfatteren har fylt ut ICMJE-skjemaet og oppgir ingen interessekonflikter.

\section{ASHWINI SETHUPATHY}

Ashwini Sethupathy er farmasøyt og rådgiver for klinisk forskning ved Haukeland universitetssjukehus.

Forfatteren har fylt ut ICMJE-skjemaet og oppgir ingen interessekonflikter.

\section{ØYVIND HESSELBERG}

Øyvind Hesselberg er cand.scient. i humanfysiologi, master i helseinformatikk og leder Seksjon for nasjonale kvalitetsregistre i Helse Sør-Øst.

Forfatteren har fylt ut ICMJE-skjemaet og oppgir ingen interessekonflikter.

\section{SAMELINE GRIMSGAARD}

Sameline Grimsgaard er dr.med., forskningsrådgiver ved Klinisk forskningsavdeling, Universitetssykehuset Nord-Norge og professor ved Institutt for samfunnsmedisin, UiT - Norges arktiske universitet. Hun har mangeårig erfaring med klinisk og epidemiologisk forskning og er leder for Tromsøundersøkelsen.

Forfatteren har fylt ut ICMJE-skjemaet og oppgir ingen interessekonflikter.

\section{KNUT HAGEN}

Knut Hagen er spesialist i nevrologi, professor ved Institutt for nevromedisin og bevegelsesvitenskap ved NTNU og medisinskfaglig rådgiver ved Klinisk forskningsenhet Midt-Norge, St. Olavs hospital. Forfatteren har fylt ut ICMJE-skjemaet og oppgir ingen interessekonflikter. 


\section{Pragmatiske studier er basert på kliniske data fra uselekterte pasienter i vanlig praksis. På den måten bygger studiene bro mellom evidensbasert medisin og klinisk praksis.}

Konseptet pragmatiske studier ble foreslått av Schwartz og Lellouch i 1967 og problematiserte to viktige aspekter ved utprøving av ny behandling, nemlig forståelse og beslutning (1). Tradisjonelle forklarende effektstudier (explanatory trials) har som mål å øke vår forståelse ved å vise om en behandling virker per se, ofte under optimale forhold med nøye utvalgte studiedeltakere og utfallsmål. Pragmatiske studier skal derimot vise om en behandling virker i den kliniske hverdagen, helst på alle typer av aktuelle pasienter. Større bredde i pasientutvalget kan potensielt gjøre det vanskeligere å påvise klinisk relevante forskjeller, og studiene må av denne grunn ofte inkludere et stort antall pasienter.

«Pragmatiske studier skal vise om en behandling virker i den kliniske hverdagen, helst på alle typer av aktuelle pasienter»

Den ideelle pragmatiske studien inkluderer en uselektert pasientgruppe som er aktuell for en type klinisk behandling, med endepunkter og oppfølging som i størst mulig grad foregår i den kliniske rutinen. Resultatene gir oss virkelighetsdata som kan understøtte beslutningen om å innføre en ny behandlingsform på generelt grunnlag. Pragmatiske studier er av interesse for beslutningstakere, fordi denne studieformen også tar sikte på å besvare spørsmål om kostnadseffekt av ny behandling som skal benyttes i alle deler av helsetjenesten.

\section{Kunstig todeling}

Pragmatiske studier har fått økt oppmerksomhet de siste årene (2,3). Å $ø$ ke kompetansen på dette området er blitt et viktig innsatsområde i Nasjonal handlingsplan for kliniske studier (4). Antallet treff i PubMed med søkeordet "pragmatic» har økt eksponentielt siden 1990-årene, og flere store skandinaviske studier med pragmatiske trekk har de siste årene blitt publisert i prestisjetunge tidsskrifter (5, 6 ). Forklarende og pragmatiske studier blir ofte satt opp mot hverandre som definerte motpoler, men en slik todeling er unaturlig og gjør oss ikke bedre i stand til å utvikle og gjennomføre de beste kliniske studiene. Få eller ingen kliniske studier er fullstendig pragmatiske, og alle studier vil befinne seg på en glidende skala fra forklarende til pragmatisk. Hvor man ender opp på et slik skala, er ikke avgjørende. Det er forskningsspørsmålet og hvordan dette best mulig kan besvares, som bestemmer de metodiske valgene man gjør. Det har ingen hensikt å være så pragmatisk som mulig dersom et annet studiedesign gir et mer presist svar på forskningsspørsmålet.

«Det har ingen hensikt å vcere så pragmatisk som mulig dersom et annet studiedesign gir et mer presist svar på forskningsspørsmålet»

\section{Pragmatisk tilnærming}

Til tross for at grensene mellom forklarende og pragmatiske studier kan være flytende, finnes det verktøy som kvantiterer grad av pragmatisme i kliniske studier. PRECIS (Pragmatic-Explanatory Continuum Indicator Summary) ble utviklet i 2009 både som et skåringssystem og en visuell framstilling for å vurdere pragmatiske trekk ved en klinisk studie. I 2015 kom skåringssystemet PRECIS-2 (7.), som inneholder ni ulike domener med en skåring fra 1 (svært forklarende, optimale forhold) til 5 (svært pragmatisk, klinisk hverdag). Med en slik omfattende kvantifisering vil de fleste studier ha pragmatiske trekk, og de 
færreste vil være utelukkende forklarende eller pragmatiske. Både for klinikere og forskere er det viktig å forstå mulighetene som ligger i pragmatiske studier, hvilke trekk som definerer de pragmatiske studiene og hvordan pragmatiske elementer kan benyttes i egen forskning.

Ved utprøving av ny behandling vil det mest pragmatiske være å inkludere alle aktuelle pasienter som på eget initiativ oppsøker helsetjenesten enten på sykehus, i poliklinikk eller i kommunehelsetjenesten. Tradisjonelle forklarende studier har typisk en streng utvelgelse av pasienter, der overføringsverdien til klinisk praksis blir mindre. De norske nasjonale kvalitetsregistrene utgjør en særstilling med tanke på rekruttering til pragmatiske kliniske studier, med anledning til å inkludere og følge opp pasienter direkte i de etablerte systemene uten behov for studiespesifikke oppfølgingsbesøk (므).

Hvis man ønsker å undersøke behandling av pasienter med akutt hjertesvikt på ulike lokalsykehus, så kan ikke pasientene inkluderes ved høyspesialiserte universitetsklinikker - eller motsatt. I så tilfelle er det ønskelig å gjennomføre studien så nært som mulig opp til den kliniske praksisen hvor resultatene skal tas i bruk. Enkeltsenterstudier innebærer redusert overføringsverdi og lavere grad av pragmatisme dersom resultatene av studien $i$ utgangspunktet er ment å benyttes også utenfor selve studiesenteret.

Det pragmatiske elementet reduseres dersom en studie krever spesifikk opplæring, ressurser eller ekspertise som rutinemessig ikke finnes i helsetjenesten. Det mest pragmatiske vil være å benytte personell og ressurser som allerede er tilgjengelig i helsevesenet for å tilby behandlingen. Ny behandling kan da sammenliknes med en kontrollgruppe som mottar standardbehandling. En legemiddelstudie kan eksempelvis være pragmatisk hvis pasientene randomiseres til medikamentell intervensjon eller ikke, der dosering og valg av studiemedikament overlates til behandlende lege. Ett eksempel på dette finnes i den norske BETAMI-studien (BEtablocker Treatment After Acute Myocardial Infarction)(9). I denne studien randomiseres pasienter som har blitt revaskularisert etter hjerteinfarkt til behandling med betablokkere eller ikke. Behandlende lege inkluderer pasienten til studien og velger spesifikk type betablokker og dosering. Pasienter i kontrollgruppen vil ikke motta placebotabletter.

Motsatsen til denne typen pragmatiske studier vil eksempelvis omfatte spesifikke medikamenter med spesifikke doser og doseringsintervaller, der effekten av behandlingen sammenliknes med placebokontroll.

\section{Fortolkning}

Fortolkningen av studieresultatene vil påvirkes av pasientenes etterlevelse (adherence). Grad av pragmatisme bestemmes av hvor fleksible vi tillater oss å være overfor behandlingsetterlevelse. Med et pragmatisk design lar vi behandler og pasient styre behandlingen uten at forskerne bruker ressurser på kontroll av etterlevelse. I forklarende studier brukes mye ressurser på medikamentregnskap for å sikre at all studiemedikasjon er inntatt i korrekt mengde, med mulighet for ekstra oppfølging for å korrigere atferd og i ytterste konsekvens ekskludere pasienter som ikke har oppnådd tilstrekkelige doser av studiemedikasjonen.

\section{«Ett av de viktigste trekkene er fokuset på endepunkter som har betydning for både pasienter og beslutningstakere»}

Ett av de viktigste trekkene med pragmatiske studier er fokuset på endepunkter som har betydning for både pasienter og beslutningstakere. Død, sykelighet, livskvalitet og sykehusinnleggelse er alle endepunkter som er viktige for pasientene, i motsetning til 
eksempelvis detaljer om endringer i venstre ventrikkels ejeksjonsfraksjon eller tumorstørrelse. Bruk av endepunkter som krever mye ressurser og spesialisert personell (eksempelvis bildediagnostikk og laboratorieanalyser), gjør studien mindre pragmatisk.

Det er to prinsipielle metoder for analyse av resultater i kliniske studier:

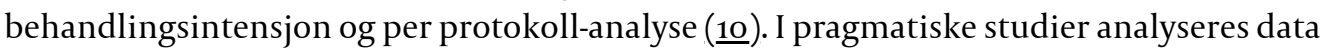
etter behandlingsintensjon, det vil si at alle pasientene som ble randomisert til behandlingen, sammenliknes med alle pasienter som ble randomisert til kontrollgruppen. Dette samsvarer med pragmatiske studiers fokus på intensjonen med behandlingen, der randomiseringen avgjør hvilken gruppe du tilhører. Forklarende studier vil i større grad benytte per protokoll-analyse. I disse blir kun pasientene med tilstrekkelig etterlevelse inkludert i analysen. Dette tillater analyse av biologiske effekter under best mulig forutsetninger, men gjør at resultatene i mindre grad kan generaliseres til å gjelde for alle pasienter. Behandlingsintensjonsanalyse vil i de fleste tilfeller øke generaliserbarheten av studieresultatene.

\section{Fordrer bedre datatekniske løsninger}

Nasjonal handlingsplan for kliniske studier oppfordrer til bruk av helsedata i kliniske studier, samarbeid med næringsliv og nye studier med pragmatisk design (4). Identifisering av pasienter i nasjonale kvalitetsregistre kan danne et omfattende grunnlag for pragmatiske studier, hvor det vil være mulig å rekruttere, randomisere og følge opp pasientene gjennom registeret. Før oppstart av slike studier kan det være behov for spesifikke datatekniske tilpasninger. Disse kan være både tids- og kostnadskrevende, men raskere og mer kostnadseffektiv inklusjon vil over tid kunne veie opp for dette.

God infrastruktur er nødvendig for å unngå dobbeltregistrering og for å sikre god datakvalitet i pragmatiske studier. Egnede kliniske fagsystemer som både styrer dataflyt og tillater registrering av journal- og registerdata, der også pasientene kan administrere samtykker til forsknings- og kvalitetsprosjekter, kan være en god hjelp. Effektive løsninger vil også ha overføringsverdi til framtidige studier i andre nasjonale registre og styrke en nasjonal innsats for pragmatiske studier.

Ved Akershus universitetssykehus har vi etablert et sentralisert datavarehus. Her kan forskere med hjelp fra analyseavdelingen trekke ut informasjon fra de kliniske systemene til screening av potensielle pasienter og innhenting av systematisk registrert pasientinformasjon. Tidlig under koronaviruspandemien muliggjorde datavarehuset både rask inklusjon av pasienter til kliniske behandlingsstudier og hurtig avklaring av potensielt virksom behandling hos covid-19-pasienter (11).

\section{Konsekvenser av pragmatisk design}

De pragmatiske trekkene som styrker ekstern validitet, kan gå på bekostning av intern validitet. Fravær av placebokontroll kan øke risikoen for at pasienter trekker seg fra studier og dermed påvirke pasientrapporterte resultatmål. Heterogene pasientgrupper med ulik behandlingsrespons og varierende grad av etterlevelse kan skape usikkerhet rundt resultatene og øke risiko for type II-feil ved at analysen ikke identifiserer en reell behandlingseffekt.

Et resultat av disse utfordringene er i ytterste konsekvens at forskere blir tilbakeholdne med å initiere og gjennomføre studier med svært pragmatisk design, da det er en fare for negative funn med lite prestisje. Til tross for $\emptyset \mathrm{kt}$ fokus på publikasjonsskjevhet i medisinsk forskning vil særlig unge forskere i starten av en akademisk karriere være mindre

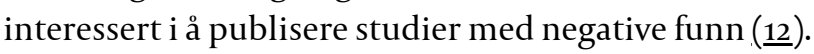

\section{Ulikt lovverk, samme mål}


Ulike lover og forskrifter regulerer klinisk praksis, forskning og kvalitetssikring. Dette gir en juridisk utfordring, for eksempel når man i pragmatiske studier samler forskningsdata som ledd i kliniske behandlingsløp. Selv om behandling, forskning og kvalitetssikring er atskilt juridisk, synliggjør pragmatiske studier hvor tett behandling, kvalitetsregister og forskning er knyttet sammen når man benytter data som allerede innhentes i helsetjenesten. Dette påvirker både søknadsprosedyrer rundt etikk og personvern og samtykkekrav for bruk av data fra elektronisk pasientjournal og nasjonale registre.

\section{«Flere kliniske studier med pragmatiske trekk vil gi bedre pasientbehandling»}

Flere kliniske studier med pragmatiske trekk vil gi bedre pasientbehandling. Forklarende randomiserte kontrollerte studier danner kunnskapsgrunnlaget for etablert pasientbehandling, men bør først og fremst informere oss om biologiske effekter under ideelle forutsetninger. Kliniske studier med pragmatiske elementer gjenspeiler i større grad den kliniske hverdagen, har høyere overføringsverdi og kan gi oss virkelighetsdata som vil hjelpe både beslutningstakere, klinikere og pasienter til å velge den beste behandlingen.

\section{LITTERATUR}

1. Schwartz D, Lellouch J. Explanatory and pragmatic attitudes in therapeutical trials. J Chronic Dis 1967; 20: 637-48. [PubMed][CrossRef]

2. Hjelmesæth J. Randomised studies-useful for whom? Tidsskr Nor Legeforen 2014; 134: 1819. [PubMed]

3. Stensrud MJ. La oss være pragmatiske. Tidsskr Nor Legeforen 2019; 139. doi: 10.4045/tidsskr.19.0059. [PubMed][CrossRef]

4. Helse- og omsorgsdepartementet. Nasjonal handlingsplan for kliniske studier 2021-2025. https://www.regjeringen.no/contentassets/59ffc7b38a4f46fbbo62aecae5oe272d/207035_kliniske_studi er_k6_b.pdf Lest 31.8.2021.

5. Hofmann R, James SK, Jernberg T et al. Oxygen Therapy in Suspected Acute Myocardial Infarction. N Engl J Med 2017; 377: 1240-9. [PubMed][CrossRef]

6. Bønaa KH, Mannsverk J, Wiseth R et al. Drug-Eluting or Bare-Metal Stents for Coronary Artery Disease. N Engl J Med 2016; 375: 1242-52. [PubMed][CrossRef]

7. Loudon K, Treweek S, Sullivan F et al. The PRECIS-2 tool: designing trials that are fit for purpose. BMJ 2015; 350: h2147. [PubMed][CrossRef]

8. Leta TH, Gjertsen JE, Dale H et al. Antibiotic-Loaded Bone Cement in Prevention of Periprosthetic Joint Infections in Primary Total Knee Arthroplasty: A Register-based Multicentre Randomised Controlled Non-inferiority Trial (ALBA trial). BM] Open 2021; 11: eo41096. [PubMed][CrossRef]

9. Munkhaugen J, Ruddox V, Halvorsen S et al. BEtablocker Treatment After acute Myocardial Infarction in revascularized patients without reduced left ventricular ejection fraction (BETAMI): Rationale and design of a prospective, randomized, open, blinded end point study. Am Heart J 2019; 208: 37-46. [PubMed][CrossRef]

10. Stensrud MJ. Er det intensjonen som teller? Tidsskr Nor Legeforen 2019; 139. doi: 10.4045/tidsskr.18.0956. [PubMed][CrossRef]

11. Lyngbakken MN, Berdal JE, Eskesen A et al. A pragmatic randomized controlled trial reports lack of efficacy of hydroxychloroquine on coronavirus disease 2019 viral kinetics. Nat Commun 2020; 11: 5284. [PubMed][CrossRef]

12. Nimpf S, Keays DA. Why (and how) we should publish negative data. EMBO Rep 2020; 21: e49775. [PubMed][CrossRef]

Publisert: 11. oktober 2021. Tidsskr Nor Legeforen. DOI: 10.4045/tidsskr.21.049o

Mottatt 14.6.2021, godkjent 31.8.2021.

(C) Tidsskrift for Den norske legeforening 2023. Lastet ned fra tidsskriftet.no 26. april 2023. 
